\title{
Study of potential availability of heavy metals to phytoremediation to use of ash from biomass combustion
}

\author{
Sitarz-Palczak E., Galas D.* and Kalembkiewicz J. \\ Department of Inorganic and Analytical Chemistry, Faculty of Chemistry, Rzeszow University of Technology, 6 Powstancow Warszawy \\ Ave., 35-959 Rzeszow, Poland
}

Received: 19/02/2018, Accepted: 17/09/2018, Available online: 26/09/2018

*to whom all correspondence should be addressed: e-mail: dgalas@stud.prz.edu.pl

https://doi.org/10.30955/gnj.002632

\begin{abstract}
Ashes, formed as a result of combustion of biomass are a new class of by-products of combustion and due to the large variety of these materials their chemical composition has not been fully determined. Their use is limited, despite the fact that their production has increased.
\end{abstract}

This work presents the results of studies on the possibility of limiting the potential availability of $\mathrm{Cu}, \mathrm{Mn}, \mathrm{Pb}$ and $\mathrm{Zn}$ for plants by use of an inorganic stabilizer - ash from biomass combustion. In this study the usefulness of ash from biomass for binding mobile fractions of heavy metals $(\mathrm{Cu}, \mathrm{Mn}, \mathrm{Pb}$ and $\mathrm{Zn}$ ) was evaluated. The investigations were executed using three extraction tests with the use of the following extraction solutions: $1 \mathrm{M} \mathrm{HNO}_{3}$ - acid soluble forms (As), 0.05 M EDTA - bioavailable forms (Bio), 2.5\% $\mathrm{CH}_{3} \mathrm{COOH}$ - exchangeable forms (Ex). The values of the following parameters: Mobility Index (MI), Contamination Factor (CF), Pollution Load Index (PLI), Geo - accumulation Index (Igeo) and Ecological Risk Index (RI) were defined and determined for their suitability as a test soil stabilizer. Furthermore, a multivariate statistical analysis was carried out.

It was found, that a phytoremediation process using investigated ash from biomass combustion can be applied to soil contaminated by heavy metals.

Keywords: Aided phytostabilization, biomass ash, FAAS, mobility of metal, stabilizer.

\section{Introduction}

The ecotoxicological condition of soils in the world is one of the most serious environmental problems, especially in relation to heavily urbanized and industrialized areas. According to a report on the state of the environment prepared by the European Environment Agency in 2015, in Europe there were about 3 million areas which were potential sources of emission of pollutants, especially heavy metals and mineral oils (EEA, 2015). In Poland, soil contamination occurs locally and applies primarily to industrial areas (Kabata-Pendias, 2011). Nevertheless, it was found that in the vicinity of former and current sources of emissions an exceeding of established values for heavy metals, defined in the relevant legal acts, for example, the Regulation of the Minister of Environment (Poland) or US EPA Standards (USA), occurs. The high toxicity of heavy metals, their ability to accumulate and their ease of penetration through biological membranes cause, heavy metals to have a negative influence on various physiological processes occurring in microorganisms, plants, animals and humans (Kabata-Pendias, 2011). To reduce the toxic effects of metals on living organisms, it is necessary to lower the bioavailability or reduce the contents of these elements in soil. This can be achieved by implementing physicochemical or biological methods. There is a wide range of physicochemical methods enabling reduction of bioavailability or removal of heavy metals from the soil. The most commonly described are: solidification (Aboulroos et al., 2006; Chen et al., 2009; Gollmann et al., 2010; Voglar and Leŝtan, 2010), vitrification (Chou et al., 2011; Kuo et al., 2009), thermal extraction (Mulligan et al., 2001a,b), chemical extraction of metals (Moon et al., 2016), electrokinetic and electrochemical removal (Korolev, 2008; Mulligan et al., 2001b; Suér et al., 2003), lessivage or removal of topsoil (Kos and Leŝtan, 2004a,b; Zhang et al., 2010).

In the remediation process of soils contaminated by heavy metals, noteworthy are minimally invasive remediation solutions (GRO - "gentle" remediation options) (Cundy et al., 2013). These include the phytoremediation methods, among others, phytoextraction and aided phytostabilization which seem to be the most promising strategies for remediation of areas contaminated with heavy metals (Koptsik, 2014; Lee et al., 2014; Pavel et al., 2014;). Aided phytostabilization is a combination of phytostabilization with chemical immobilization of heavy metals with the use of various organic and inorganic materials called stabilizers, which are administered into the soil. They have a high sorption capacity, which enables them to bind the mobile fraction of heavy metals, and thus lower their bioavailability and toxicity. Examples of stabilizers used in the aided phytostabilization process include: alkaline compounds - 
they are administered into the soil in the form of various calcium compounds, for example, $\mathrm{CaCO}_{3}, \mathrm{CaO}, \mathrm{Ca}(\mathrm{OH})_{2}$, $\mathrm{CaMg}(\mathrm{CO})_{3}$ (Lombi et al., 2002; Paulose et al., 2007; Verdugo et al. 2011); their addition is not recommended for soils contaminated with $\mathrm{Cr}$ and $\mathrm{Mn}$ due to the high mobility of these elements (Koptsik, 2014); phosphorus compounds e.g., hydroxyapatite (Guo et al., 2006; Kumpienie, 2010) or phosphates(V) calcium, ammonium, potassium and sodium (Nzihou and Sharrock, 2010) - their usage is recommended for the immobilization of $\mathrm{Pb}$; hydrated iron oxides - for example, goethite reduces the toxicity of arsenic in the soil (Hartley and Lepp, 2008), amorphous iron(III) oxide (Warren et al., 2003), hydrated manganese oxides, especially synthetic, i.e., cryptomelane and birnessite - for immobilizing lead (Sonmez and Pierzynski, 2005); aluminosilicates, including in particular, clays (Hale and Küchnel, 1997) and zeolites (Shi et al., 2009), for example, clinoptilolite is one of the most effective molecular sieves capable of sorption of $\mathrm{Cd}, \mathrm{Pb}, \mathrm{Zn}, \mathrm{Cu}$ and $\mathrm{Pd}$. Its effectiveness supports the addition of calcium compounds (Sun et al., 2016). Fly ash from the combustion of coal is an additive that stabilizes heavy metals in the soil (Gatima et al., 2006; Gupta et al., 2002; Ram and Masto, 2014). The best stabilizing effect, after the application of fly ash from the combustion of coal into the soil, occurs in the case of contamination by heavy metals in the form of $\mathrm{Cu}, \mathrm{Pb}, \mathrm{Zn}$ and $\mathrm{Ni}$ cations (Ram and Masto, 2014).

In this paper, ash from the combustion of biomass was used as a stabilizer of heavy metals ( $\mathrm{Cu}, \mathrm{Mn}, \mathrm{Pb}$ and $\mathrm{Zn}$ ). It is a by-product (waste) received during the combustion of biomass, which is currently more widely used in the commercial power industry (CSOP Report). The evaluation of the usefulness of this stabilizer was based on defining its role in the binding of the mobile fraction of heavy metals in soil under laboratory conditions. On this basis, the efficacy of aided phytoremediation in remediation of soil contaminated with $\mathrm{Cu}, \mathrm{Mn}, \mathrm{Pb}$ and $\mathrm{Zn}$ was evaluated.

Table 1. The conditions of determination of selected metals by FAAS method

\begin{tabular}{ccccc}
\hline Parametr & $\mathbf{C u}$ & $\mathbf{M n}$ & $\mathbf{P b}$ & $\mathbf{Z n}$ \\
\hline $\begin{array}{c}\text { Wavelength } \\
(\mathrm{nm})\end{array}$ & 324.8 & 279.5 & 217.0 & 213.9 \\
\hline $\begin{array}{c}\text { Sensivity } \\
\left(\mathrm{mg} \mathrm{dm}^{-3}\right)\end{array}$ & 0.45 & 0.052 & 0.19 & 0.084 \\
\hline $\begin{array}{c}\text { Spectral } \\
\text { width slit } \\
\text { (nm) }\end{array}$ & 0.7 & 0.2 & 0.7 & 0.7 \\
\hline $\begin{array}{c}\text { Concentration } \\
\text { of standard } \\
\text { solutions } \\
\left(\mathrm{mg} \mathrm{cm}^{-3}\right)\end{array}$ & $2.0,4.0$, & $2.0,2.5$, & 9.0, & $1.0,3.0$, \\
\hline $\begin{array}{c}\text { Flow rate of } \\
\text { gas }\end{array}$ & 5.0 & $6.0,12.0$ & 20.0 & $5.0,6.0$ \\
$\left(\mathrm{dm}^{3}\right.$ min $\left.^{-1}\right)$ & & $0.8-1.0$ & \\
\hline
\end{tabular}

\section{Experimental}

\subsection{Materials}

Analyses were carried out with the use of biomass ash from CHP Arłamów (Poland), being the product of combustion of wood chips (from deciduous trees). The basic physicochemical properties of biomass ash are presented in Table 2. The experiment was performed under laboratory conditions on experimental soil sampled from the surface layer $(0-30 \mathrm{~cm})$ in the area of Rzeszow University of Technology (Poland). The primary ash and soil samples for chemical analysis were dried at room temperature to attain an air-dry state and then prepared for analysis according to the procedure described in the Polish Standard PN-77/G-04528-00.

Table 2. The physicochemical properties of biomass ash (Kalembkiewicz et al., 2018)

\begin{tabular}{c}
\hline pH \\
\hline 12.95 $\left(\mathrm{H}_{2} \mathrm{O}\right), 12.94(\mathrm{KCl}), 12.90\left(\mathrm{CaCl}_{2}\right)$ \\
\hline Bulk density \\
\hline - in uncompressed state $-0.81 \mathrm{~g} \mathrm{~cm}^{-3}$ \\
\hline - in density state $-1.25 \mathrm{~g} \mathrm{~cm}^{-3}$ \\
\hline Surface area \\
\hline $3.37 \mathrm{~m}^{2} \mathrm{~g}^{-1}$ \\
\hline Elemental analysis \\
\hline \% $-3.5, \% \mathrm{~N}-0.11, \% \mathrm{~S}-0.92, \% \mathrm{H}-0.16$ \\
\hline
\end{tabular}

2.2. Determination of total concentration of investigated metals

For the determination of the total content of investigated metals laboratory samples, for soil and ash respectively, were prepared and then mineralized in mixtures of concentrated acids ( $\mathrm{HF}$ and $\mathrm{HClO}_{4}$ for soil, $\mathrm{HF}$ and $\mathrm{HCl}$ for ash). A detailed description of mineralization procedures can be found in the literature (Kalembkiewicz et al., 2008). Determination of the concentrations of $\mathrm{Cu}, \mathrm{Mn}, \mathrm{Pb}$, and $\mathrm{Zn}$ in solutions after mineralization were performed by flame atomic absorption spectrometer (PERKIN-ELMER 3100 Model (Shelton Instruments, CT USA) in the conditions described in Table 1.

\subsection{Determination of mobile form of the investigated} metals

In order to determine the degree of mobility of $\mathrm{Cu}, \mathrm{Mn}, \mathrm{Pb}$ and $\mathrm{Zn}$ in the soil and ash from the combustion of biomass, 3 procedures of individual extraction with the use of the following extraction solutions were applied: $0.05 \mathrm{M}$ EDTA - bioavailable forms (Bio); $2.5 \% \mathrm{CH}_{3} \mathrm{COOH}$ exchangeable forms (Ex); $1 \mathrm{M} \mathrm{HNO}_{3}$ - determined forms soluble in acids (As). The procedure for each was identical, namely, into the weighed out, air-dry samples of ash or soil with mass $1.0000( \pm 0.0001) \mathrm{g}, 5 \mathrm{~cm}^{3}$ of the appropriate extraction solution was added, and the sample was then shaken on a laboratory shaker (Vibramax 100, Heidolph of Instruments, Germany) at speed $v=900$ rpm for 24 hours. Then, by centrifugation and/or filtration through a filter paper for quantitative analyses MN 616 (Macherey - Nagle, Germany), phasing was performed. Determination of the concentrations of $\mathrm{Cu}, \mathrm{Mn}, \mathrm{Pb}$, and $\mathrm{Zn}$ in the solutions from the extraction 
were performed by flame atomic absorption spectrometer PERKIN-ELMER 3100 Model (Shelton Instruments, CT USA) in the conditions described in Table 1.

2.4. Research into the possibility of limiting the availability of the metals by the use of biomass ash

Analyses of the possibility of limiting the availability of the investigated metals were carried out by adding, into the soil, biomass ash in an amount by $5 \%$ of weight in relation to the initial weight of the soil sample. After mixing the samples were left for 3 weeks at room temperature in order to stabilize their properties. Then the soil with ash was subjected to the extraction procedure in order to determine the mobile forms of $\mathrm{Cu}, \mathrm{Mn}, \mathrm{Pb}$ and $\mathrm{Zn}$. The conditions and the extraction process were described in detail in point - Determination of mobile form of the investigated metals.

\subsection{Analysis of results}

Inorganic stabilizer, that used in the aided phytostabilization process, should meet the following criteria: 1) it should effectively immobilize metals; 2) it should be cheap and easy to obtain or produce; 3) it should be non-toxic to plants and even stimulate their growth; 4) it should be devoid of any negative influence on any environmental components subjected to phytostabilization (Berti and Cunningham, 2000). Taking into account the above criteria and the results, the values of the following parameters were calculated: Mobility Index (MI), Contamination Factor (CF), Pollution Load Index (PLI), Geo - accumulation Index (Igeo) and Ecological Risk Index (RI).

On the basis of results, the values of the following parameters were calculated:

Mobility Index (MI) - is defined as the percentage of the mobile forms of element in different environmental objects (Kumar et al., 2009). This degree was calculated from the following relationship:

$\mathrm{MI}(\mathrm{Me})=\frac{[\mathrm{Me}]}{[\mathrm{Me}]_{\text {experim. }}} 100 \%$

where: $\mathrm{Ml}_{(\mathrm{Me})}$ - degree of mobility of particular element, $\%$; [Me] - concentration of metal in mobile forms, $\mathrm{mg} \mathrm{kg}^{-1}$; [Me $]_{\text {experim. }}$ - total concentration of metal, $\mathrm{mg} \mathrm{kg}^{-1}$.

Contamination Factor (CF) - is defined as the quotient of the concentrations of the different metals in the soil with addition of stabilizer and concentrations of these metals in the soil experimental (Ghannem et al., 2016). Contamination factor was calculated from following formula:

$\mathrm{CF}(\mathrm{Me})=\frac{[\mathrm{Me}]_{\text {stab. }}}{[\mathrm{Me}]_{\text {experim. }}}$

where: $\mathrm{CF}_{(\mathrm{Me})}$ - contamination factor for particular element; $[\mathrm{Me}]_{\text {stab. }}$ - concentration of metal in soil with addition of stabilizer, $\mathrm{mg} \mathrm{kg}^{-1}$; [Me] experim. - total concentration of metal in experimental soil, $\mathrm{mg} \mathrm{kg}^{-1}$.
The values of the contamination factor (CF) were interpreted as follows:

- if $\mathrm{CF}<1$ - there is low level of impurities,

- if $1<\mathrm{CF}<3$ - there is moderate level of impurities,

- if $3<\mathrm{CF}<6$ - there is high level of impurities

- if CF $>6$ - there is very high level of impurities

(Ghannem et al., 2016).

Pollution Load Index (PLI) - is defined as the square root of n-the degree of the pollution factor for individual environmental objects or heavy metal (Ghannem et al., 2016). This index is calculated from the following relationship:

$$
\mathrm{PLI}=\sqrt[n]{\mathrm{CF}_{1} \cdot \mathrm{CF}_{2}} \cdot \ldots \cdot \mathrm{CF}_{\mathrm{n}}
$$

where: $\mathrm{PLI}$ - pollution load index; $\mathrm{CF}_{\mathrm{n}}$ - pollution factor for individual environmental object.

If $\mathrm{PLI}>1$ - this means that there is contamination by heavy metals in individual object, whereas if $\mathrm{PLI}<1$ - there is no contamination of heavy metal (Ghannem et al., 2016).

Geo - accumulation Index (Igeo), were calculated from following equation:

$\mathrm{I}_{\text {geo }}=\log _{2}\left(\frac{[\mathrm{Me}]_{\text {stab. }}}{1.5 \cdot[\mathrm{Me}]_{\text {experim. }}}\right)$

where: Igeo - geo - accumulation index; $[\mathrm{Me}]_{\text {stab. }}$ concentration of metal in soil with addition of stabilizer, $\mathrm{mg} \mathrm{kg}^{-1}$; [Me] experim. - total concentration of metal in experimental soil, $\mathrm{mg} \mathrm{kg}^{-1}$ (Ghannem et al., 2016).

Geo - accumulation index includes seven classes described below (Ghannem et al., 2016):

- class $0-$ no contamination: $\operatorname{Igeo}_{\text {ge }} \leq 0$,

- class 1 - low contamination: $0<I_{\text {geo }}<1$,

- class 2 - moderate contamination: $1<I_{\text {geo }}<2$,

- class 3 - moderate to high contamination: $2<$ Igeo $<3$,

- class 4 - high contamination: $3<\operatorname{l}_{\text {geo }}<4$,

- class 5 - high to very high contaminatio: $4<$ Igeo $_{\text {ge }}$ 5,

- class 6 - very high contamination: $I_{\text {geo }}>5$.

Ecological Risk (Index, RI) - is the sum of the factors involved in the potential threat environmental objects by heavy metals (Hu et al., 2013; Chai et al. 2016). Ecological Risk is calculated from formula:

$\mathrm{RI}=\Sigma \mathrm{E}(\mathrm{Me})$

where: $E_{(\mathrm{Me})}$ - single risk factor for the metal defined by the equation below as:

$E(M e)=T(M e) \cdot C F(M e)$

where: $\mathrm{T}_{(\mathrm{Me})}$ - toxic agent response for the metal, the value for $\mathrm{Cu}, \mathrm{Mn}, \mathrm{Pb}$ and $\mathrm{Zn}$ are successively: 5, 1, 5, and 
1; $\mathrm{CF}_{(\mathrm{Me})}$ - contamination factor for metal (Hu et al., 2013; Chai et al. 2016).

\subsection{Statistical analysis}

The statistical analysis of the obtained results was performed based on the Pearson linear correlation coefficient and hierarchical cluster analysis. For this Statistica 12.5 program was used.

\section{Results}

\subsection{Determination of total concentration of the investigated metals}

The presence of heavy metals in the soil is generated by two essential sources, natural and anthropogenic. In assessing the degree of contamination of the soil by a particular metal we should take account of its natural content in the bedrock, and the content related to human activity. Execution of mineralization allowed the determination of the total content of the investigated metals in the soil and biomass ash. The results are presented in Table 3.

\subsection{Determination of the mobile form of the investigated metals}

The assessment of the most important sources of threats for humans and the ecosystem is not associated with the total content of heavy metals in the soil, but only with their forms that are currently or can be potentially assimilated. In the case of the threat to microflora and microfauna of the soil, these are mainly soluble and colloidal forms of heavy metals present in the soil solution.

Table 3. Total concentration of investigated metals in soil and biomass ash ( $n=5, p=95 \%)$

\begin{tabular}{ccc}
\hline \multirow{2}{*}{ Metal } & \multicolumn{2}{c}{ Content of metal $\left(\mathbf{m g ~ k g}^{-1}\right)$} \\
\cline { 2 - 3 } & Experimental soil & Biomass ash \\
\hline $\mathrm{Cu}$ & $29.99( \pm 0.0)$ & $37.67( \pm 1.88)$ \\
\hline $\mathrm{Mn}$ & $375.18( \pm 35.85)$ & $3600.0( \pm 100.0)$ \\
\hline $\mathrm{Pb}$ & $96.85( \pm 5.03)$ & $90.23( \pm 4.51)$ \\
\hline $\mathrm{Zn}$ & $113.29( \pm 39.86)$ & $73.8( \pm 3.69)$ \\
\hline
\end{tabular}

The obtained results of the determination of the different mobile forms, including bioavailable (Bio), exchangeable (Ex) and acid soluble (As) forms of $\mathrm{Cu}, \mathrm{Mn}, \mathrm{Pb}$ and $\mathrm{Zn}$ in investigated samples, i.e. experimental soil, biomass ash and soil with addition of ash are presented in Table 4. To assess the content of mobile forms of the investigated metals solutions of acids were used, respectively $\mathrm{HNO}_{3}$ - for the extraction of acid-soluble forms (As) and $\mathrm{CH}_{3} \mathrm{COOH}$ - for the extraction of exchangeable forms (Ex). These solutions extracted the above-mentioned forms of metals present in the soil solution and those that are potentially available for plants in the event of a change in soil conditions. EDTA was used to extract bioavailable forms (Bio). Its advantage is that it does not destroy the mechanical structure of the soil and has a relatively small effect on its biological activity. What's more, it shows a very good correlation between the content of metal in the plant and in the extracted fraction (Xia et al., 2009).

Table 4. The content of mobile form of investigated metals in soil, biomass ash and in soil with addition of ash ( $n=5, p=95 \%)$

\begin{tabular}{|c|c|c|c|}
\hline \multirow{2}{*}{ Metal } & \multicolumn{3}{|c|}{ Content of metal $\left(\mathrm{mg} \mathrm{kg}^{-1}\right)$} \\
\hline & Experimental soil & Biomass ash & Soil with addition of ash \\
\hline $\mathrm{Cu}$ (Bio) & $4.99( \pm 0.01)$ & $<$ l. d. & $10.35( \pm 3.85)$ \\
\hline $\mathrm{Cu}(\mathrm{Ex})$ & $5.0( \pm 0.01)$ & $<$ l. d. & $15.75( \pm 3.25)$ \\
\hline $\mathrm{Cu}(\mathrm{As})$ & $9.99( \pm 0.01)$ & $25.11( \pm 0.01)$ & $51.25( \pm 0.85)$ \\
\hline Mn (Bio) & $<$ l. d. & $<$ l. d & $12.76( \pm 1.98)$ \\
\hline$M n(E x)$ & $<$ l. d. & $<$ l. d & $30.75( \pm 2.54)$ \\
\hline $\mathrm{Mn}(\mathrm{As})$ & $317.83( \pm 30.9)$ & $239.88( \pm 33.86)$ & $61.49( \pm 2.97)$ \\
\hline $\mathrm{Pb}$ (Bio) & $19.19( \pm 15.18)$ & $<1 . d$ & $1.17( \pm 0.85)$ \\
\hline $\mathrm{Pb}(\mathrm{Ex})$ & $45.98( \pm 6.8)$ & $<$ l. d & $15.0( \pm 0.75)$ \\
\hline $\mathrm{Pb}(\mathrm{As})$ & $27.48( \pm 7.96)$ & $59.37( \pm 2.97)$ & $103.58( \pm 5.18)$ \\
\hline Zn (Bio) & $<$ l. d. & $16.92( \pm 0.85)$ & $23.38( \pm 6.88)$ \\
\hline $\mathrm{Zn}(\mathrm{Ex})$ & $<$ l. d. & $22.28( \pm 1.14)$ & $35.43( \pm 3.87)$ \\
\hline $\mathrm{Zn}(\mathrm{As})$ & $15.99( \pm 6.8)$ & $23.59( \pm 1.18)$ & $43.53( \pm 5.12)$ \\
\hline
\end{tabular}

l. d. - limit of detection

\section{Discussion}

\subsection{Analysis of results}

The addition of additives into the soil during the aided phytostabilization process aims at transforming ionic forms and readily soluble metal compounds into sparingly or high sparingly soluble forms. This takes place by the following processes: sorption of metals, metal precipitation from solution, change in oxidation state of metals, humification, formation of secondary minerals containing metals. As a result, there is a reduction in leaching of metals and their absorption by plants, microorganisms, invertebrates and vertebrates (Chaney et al., 2010). When formulating conclusions about the content of mobile forms of $\mathrm{Cu}, \mathrm{Mn}, \mathrm{Pb}$ and $\mathrm{Zn}$, it must be taken into account that the real concentration of metal in the soil solution depends not only on the maximum amount of metal susceptible for desorption (or immobilization due to other processes) but also from the balance of the sorption - desorption processes at the boundary between the solid phase and the solution. In single extractions performed, consisting of shaking samples with appropriate extraction solutions, the position of the equilibrium of these processes depends on the quantitative ratio of the solid phase to the extraction solution and is achieved at different times of shaking. 
With an excess of solution relative to the solid phase there is a strong shift of the equilibrium towards desorption, while under natural conditions in the soil - in the direction of sorption, which affects the limitation of the mobility of the investigated metals. In connection with the above, the extraction solutions used: $\mathrm{HNO}_{3}, \mathrm{CH}_{3} \mathrm{COOH}$ and EDTA can be used only to assess the potential, and not the current, content of mobile forms of $\mathrm{Cu}, \mathrm{Mn}, \mathrm{Pb}$ and $\mathrm{Zn}$.

The assessment of the content of heavy metal in soils and the content of chemical forms of these metals should take into account the physical and chemical properties of soils that in a specific way modify the mobility of heavy metals and their bioavailability. The physicochemical properties of soils on which the solubility of metals depends include: soil type, $\mathrm{pH}$, oxidation-reduction potential, organic matter content, sorptive properties and granulometric composition (Bravo et al., 2107). The $\mathrm{pH}$ of soil is one of the main factors affecting the form in which metals occur in the soil and to what extent they are available to plants (Teng et al., 2015). At slightly acidic and acidic $\mathrm{pH}$, heavy metals exhibit an increase in the concentration of forms that are bioavailable in the soil solution, thus increasing the rate of their accumulation in plants. The reason is the increased solubility of chemical compounds of these metals and the reduction of their absorption on soil colloids at acidic pH of soil (Likar et al., 2015).

In the presented studies, the $\mathrm{pH}$ of soil increases after adding ash from biomass combustion. Saletnik et al. (2016) in their research also found an increase in the $\mathrm{pH}$ value of soil after adding ash from biomass combustion. The addition of ash caused a decrease in the content of mobile forms of $\mathrm{Mn}$ and $\mathrm{Pb}$, by $78 \%$ and $31 \%$ respectively, and an increase in the content of mobile forms of $\mathrm{Zn}$ by $71 \%$. In connection with the obtained results, it can be concluded that an increase in $\mathrm{pH}$ of soil does not always reduce the concentration of heavy metal forms available for plants. This is associated with the formation of mobile inorganic compounds of these metals with fine molecules of organic matter that are easily absorbed by plants. In general, ash from biomass combustion increases the $\mathrm{pH}$ of soil and promotes the formation of oxides, hydroxides and carbonates, which as a consequence leads to a decrease in the solubility of $\mathrm{Mn}$ and $\mathrm{Pb}$ (Fraser et al., 2016).

On the basis of values of degrees of mobility of individual elements, it was estimated that the degree of mobility of $\mathrm{Mn} \mathrm{(84.71 \% )}$ and $\mathrm{Pb}$ (96.49\%) in the experimental soil, significantly decreases after application of biomass ash and amounts to $6.66 \%$ and $65.8 \%$, respectively. However, the mobility of $\mathrm{Zn}$ for soil containing ash $(85.08 \%)$ increases in comparison to soil without the addition of this stabilizer (14.11\%). In turn, the degree of mobility of $\mathrm{Cu}$, in all investigated samples, is maintained at the same level, i.e., approximately $67.6 \%$ (Figure 1).

By analysing the results presented in Table 5, it was found that the concentration of $\mathrm{Mn}$, that contaminates soil with the addition of ash from the combustion of biomass is at a high level. The degrees of contamination of $\mathrm{Cu}, \mathrm{Pb}, \mathrm{Zn}$ can be described as equable. The value of the geo-accumulation index for $\mathrm{Mn}$ indicates a fluctuation from moderate to high contamination of soil with the addition of ash. Igeo values obtained for $\mathrm{Cu}, \mathrm{Pb}$ and $\mathrm{Zn}$ confirm low levels of contamination for soil with the addition of ash from the combustion of biomass. The obtained value of the Pollution Load Index (PLI) for soil with the addition of ash informs about the presence of contamination with $\mathrm{Cu}, \mathrm{Mn}, \mathrm{Pb}$ and $\mathrm{Zn}$ in the analysed sample. Analysis of the results (Figure 2) indicates that the highest concentrations among the investigated metals in the experimental soil containing ash from the combustion of biomass, in relation to the potential ecological threat to the surface layer of the soil, can be found in $\mathrm{Cu}(34.04 \%), \mathrm{Mn}$ (31.93\%), $\mathrm{Pb}(29.07 \%)$, and $\mathrm{Zn}$ (4.97\%). The total value of the ecological risk index for soil with the addition of biomass ash is 33.2.

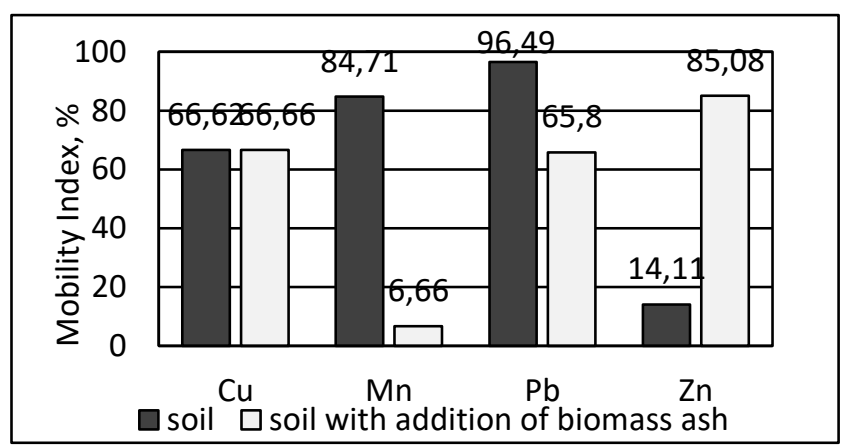

Figure 1. The degree of mobility (\%) of investigated heavy metals in the soil and in soil with addition biomass ash

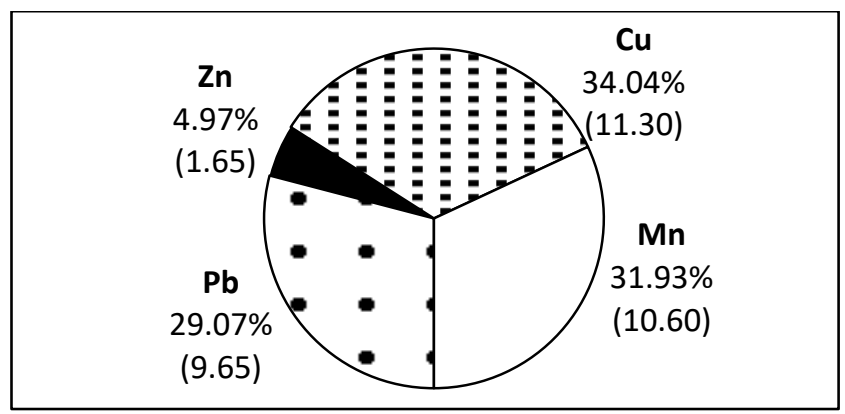

Figure 2. The share of the investigated metals in the soil with addition of ash in relation to the potential environmental risk of the surface layer of soil

As can be seen, the comparison of results of risk values of heavy metals based on different methods show that there are several disagreements. Most of these paradoxes in evaluation are mainly dependant on the total content of heavy metals as a criterion for determining their potential effect on the environment. Whereas in a comprehensive manner, in addition to total concentrations, environmental risk evaluation methods will provide useful information for assessing metal bioavailability or toxicity. The results also show the importance of soil metal mobility on metal transfers to plants, and determination of efficient extraction methods for measuring bioavailable metals. 
Table 5. The summary of the designated parameters for soil with the addition of biomass ash

\begin{tabular}{|c|c|c|c|c|c|c|}
\hline Metal & MI (\%) & CF & Degree of contamination & PLI & $I_{\text {geo }}$ & Geo - accumulation Index \\
\hline $\mathrm{Cu}$ & 66.66 & 2.26 & moderate & \multirow{4}{*}{2.96} & 0.58 & low contamination \\
\hline $\mathrm{Mn}$ & 6.66 & 10.6 & very high & & 2.82 & moderate to high \\
\hline $\mathrm{Pb}$ & 65.8 & 1.93 & moderate & & 0.37 & low contamination \\
\hline $\mathrm{Zn}$ & 85.08 & 1.65 & moderate & & 0.14 & low contamination \\
\hline
\end{tabular}

\subsection{Statistical analysis}

A hierarchical cluster analysis was performed in order to analyse the chemical affinity between the analysed metals in the biomass ash. This resulted in obtaining the dendrogram presented in Figure 3. On its basis, the presence of two groups was noticed. The first group included copper and zinc - which are closely linked, and the second group included manganese and lead.

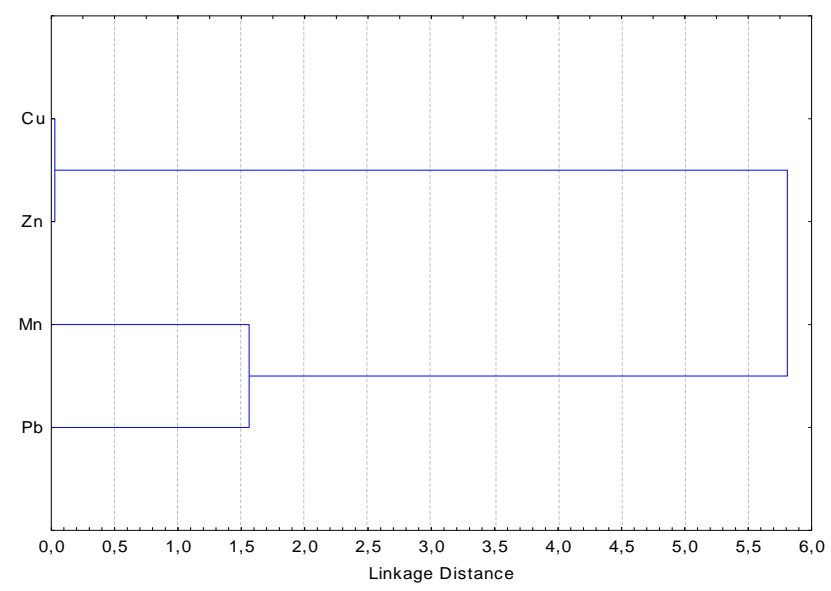

Figure 3. Dendrogram representing the cluster analysis investigated metals in the biomass ash

In order to determine the correlation between the analysed metals in the experimental soil, with the addition of biomass ash, a correlation matrix was prepared (Table 6). On the basis of Pearson's correlation coefficients, in the investigated sample, significant correlations between the contents of $\mathrm{Mn}$ and $\mathrm{Pb}(\mathrm{R}=$ 0.997), $\mathrm{Mn}$ and $\mathrm{Zn}(\mathrm{R}=0.998), \mathrm{Pb}$ and $\mathrm{Zn}(\mathrm{R}=0.988)$ were noticed. This means that an increase of $M n$ content in soil containing ash entails an increase of the $\mathrm{Pb}$ and $\mathrm{Zn}$ contents, while an increase of the $\mathrm{Pb}$ content is related to an increase of $\mathrm{Zn}$ content.

Table 6. The summary of Pearson correlation coefficients for the investigated metals in the soil with the addition of biomass ash

\begin{tabular}{ccccc}
\hline & $\mathrm{Cu}$ & $\mathrm{Mn}$ & $\mathrm{Pb}$ & $\mathrm{Zn}$ \\
\hline $\mathrm{Cu}$ & 1 & & & \\
\hline $\mathrm{Mn}$ & -0.581 & 1 & & \\
\hline $\mathrm{Pb}$ & -0.647 & $0.997^{*}$ & 1 & \\
\hline $\mathrm{Zn}$ & -0.524 & $0.998^{*}$ & $0.988^{*}$ & 1 \\
\hline
\end{tabular}

* - significance level $\alpha=0.05$

\section{Conclusion}

Contamination of soil by heavy metals is a major environmental problem. It requires the monitoring of the fate of these metals in the environment and the development and implementation of innovative solutions for their elimination and detoxification. Among the various phytoremediation methods, aided phytostabilization is a promising technology for limiting the mobility of heavy metals in soil. The addition to soil used in this work - ash from the combustion of biomass is a material that is cheap and easy to produce. In contrast to organic compounds that are synthetic surfactants, it is not an environmental problem due to biological toxicity.

The influence of ash from biomass combustion on soil largely depends on the analysed metal. Based on the obtained results, it was found that ash has immobilizing properties in relation to manganese and lead. Immobilization of metals occurs through alkalization of soil, precipitation of insoluble phases and sorption of metals after complexation processes. The influence of biomass ash on soil may be detrimental, however depending mainly on the analysed metal. Implementation of ash from the combustion of biomass in the process of aided phytostabilization is a cheap and effective method of phytoremediation with respect to manganese and lead. However, further analyses are crucial in order to determine the influence of this stabilizer on the growth and development of tested plants. Their results will help explicitly evaluate the suitability of ash from the combustion of biomass in the aided phytostabilization process.

\section{References}

Aboulroos S.A., Helal M.I.D. and Kamel M.M. (2006), Remediation of $\mathrm{Pb}$ and $\mathrm{Cd}$ polluted soils using in situ immobilization and phytoextraction techniques, Soil Sediment Contamination, 15, 199-215.

Berti W.R. and Cunningham S.D. (2000), Phytostabilization of metals. In: Raskin I. and Ensley B.D. (ed.), Phytoremediation of Toxic Metals: Using Plants to Clean Up the Environment, John Wiley and Sons Inc., New York.

Bravo S., Amorós J.A., Pérez-de-los-Reyes C., García F.J., Moreno M.M., Sánchez-Ormeño M. and Higueras P. (2017), Influence of the soil $\mathrm{pH}$ in the uptake and bioaccumulation of heavy metals ( $\mathrm{Fe}, \mathrm{Zn}, \mathrm{Cu}, \mathrm{Pb}$ and $\mathrm{Mn}$ ) and other elements ( $\mathrm{Ca}, \mathrm{K}, \mathrm{Al}$, $\mathrm{Sr}$ and $\mathrm{Ba}$ ) in vine leaves, Castilla-La Mancha (Spain), Journal of Geochemical Exploration, 174, 79-83.

Chai L., Li H., Yang Z., Min X., Liao Q., Lin Y., Men S., Yon Y. and $\mathrm{Xu}$ J. (2017), Heavy metals and metalloids in the surface sediments of the Xiangjiang River, Hunan, China: 
distribution, contamination, and ecological risk assessment, Environmental Science and Pollution Research, 24, 874-885.

Chaney R.L., Broadhurst C.L. and Centofanti T. (2010), Phytoremediation of soil trace metals. In: Hood P.S. (ed.), Trace element in soils, John Wiley and Sons Ltd., Chichester, United Kingdom.

Chen Q.Y., Tyrer M., Hills C.D. and Yang X.M. (2009), Immobilisation of heavy metals in cement-based solidification/stabilisation: a review, Waste Management, 29, 390-403.

Chou I.C., Wang Y.F., Chang C.P., Wang C.T. and Kuo Y.M. (2011), Effect of $\mathrm{NaOH}$ on the vitrification process of waste $\mathrm{Ni}-\mathrm{Cr}$ sludge, Journal of Hazardous Materials, 185, 1522-1527.

Cundy A.B., Bardos R.P., Church A., Puschenreiter M., Fries-Hanl W., Müller I., Neu S., Mench M., Witters N. and Vangronsveld J. (2013), Developing principles of sustainability and stakeholder engagement for "gentle" remediation approaches: The European context, Journal of Environmental Management, 129, 283-291.

EEA (2015), The European Environment - State and Outlook 2015: Synthesis Report, European Environmental Agency, Copenhagen (Denmark).

Fraser M.F., Churchman G.J., Chittleborough D.J. and Rengasamy P. (2016), Reprint of effect of plant growth on the occurrence and stability of palygorskite, sepiolite and saponite in salt-affected soils on limestone in South Australia, Applied Clay Science, 131, 144-157.

Gatima E., Mwinyihija M. and Killham K. (2006), Determination of adsorption efficiency based on cation exchange capacity related to red earth, bone meal and pulverised fly ash as ameliorants to lead contaminated soils, International Journal of Environmental Science and Technology, 3, 269-280.

Ghannem S., Khazri A., Sellami B. and Boumaiza M. (2016), Assessment of heavy metal contamination in soil and Chlaenius (Chlaeniellus) olivieri (Coleoptera, Carabidae) in the vicinity of a textile factory near Ras Jbel (Bizerte, Tunisia), Environmental Earth Sciences, 75, 442-452.

Gollman M.A.C., Da Silva M.M., Masuero Ă.B. and dos Santos J.H.Z. (2010), Stabilization and solidification of $\mathrm{Pb}$ in cement matrices, Journal of Hazardous Materials, 179, 507-514.

Guo, G., Zhou, Q. and Ma, L.Q. (2006), Availability and assessment of fixing additives for the in situ remediation of heavy metal contaminated soil: A review, Environmental Monitoring and Assessment, 116, 513-528.

Gupta D.K., Rai U.N., Tripathi R.D. and Inouhe M. (2002), Impacts of fly-ash on soil and plant responses, Journal of Plant Research, 115, 401-409.

Hale M. and Küchnel R.A. (1997), Exploration of contaminated soil and sediments, Applied Clay Science, 11, 373-380.

Hartley W. and Lepp N.W. (2008), Remediation of arsenic contaminated soil by iron-oxide application, evaluated in terms of plant productivity, arsenic and phytotoxic metal uptake, The Science of the Total Environmental, 390, 35-44.

Hu Y., Liu X., Bai J., Shih K., Zeng E.Y. and Cheng H. (2013), Assessing heavy metal pollution in the surface soils of a region that had undergone three decades of intense industrialization and urbanization, Environmental Science and Pollution Research, 20, 6150-6159.

Kabata-Pendias A. (2011), Trace Elements in Soils and Plants, CRC Press, US.
Kalembkiewicz J., Sitarz-Palczak E. and Zapała L. (2008), A study of the chemical forms or species of manganese found in coal fly ash and soil, Microchemical Journal, 90, 37-43.

Kalembkiewicz J., Galas D. and Sitarz-Palczak E. (2018), The physicochemical properties and composition of biomass ash and evaluation of directions of its applications, Polish Journal of Environmental Studies, 27, 1-11.

Koptsik G.N. (2008), Modern approaches to remediation of heavy metal polluted soils: A review, Eurasian Soil Science, 47, 707-722.

Korolev V.A. (2008), Electrochemical soil remediation from environmental toxicants: Results and prospects, Moscow University Geology Bulletin, 63, 11-18.

Kos B. and Leŝtan D. (2004a), Soil washing of Pb, $\mathrm{Zn}$ and Cd using biodegradable chelator and permeable barriers and induced phytoextraction by Cannabis sativa, Plant Soil, 263, 43-51.

Kos B. and Leŝtan D. (2004b), Chelator induced phytoextraction and in situ soil washing of $\mathrm{Cu}$, Environmental Pollution, 132, 333-339.

Kumar N., Soni H. and Kumar R.N. (2009), Hyperaccumulation and mobility of heavy metals in vegetable crops in India, The Journal of Agriculture and Environment, 10, 34-45.

Kumpiene J. (2010), Trace element immobilization in soils using amendments. In: Hood P.S. (ed.), Trace Element in Soils, John Wiley and Sons Ltd., Chichester, United Kingdom.

Kuo Y.M., Wang C.T., Tsai C.H. and Wang L.C. (2009), Chemical and physical properties of plasma slags containing various amorphous volume fraction, Journal of Hazardous Materials, 162, 469-475.

Lee S.H., Ji W., Lee W-S. and Park J-S. (2014), Influence of amendments and aided phytostabilization on metal availability and mobility in $\mathrm{Pb} / \mathrm{Zn}$ mine tailings, Journal of Environmental Management, 139, 15-21.

Likar M., Vogel-Mikus K., Potisek M., Hancevic K., Radic T., Necemer M. and Regvar M. (2015), Importance of soil and vineyard management in the determination of grapevine mineral composition, Science of the Total Environment, 505, 724-731.

Lombi E., Zhao F.J., Wieshammer G., Zhang G. and McGrath S.P. (2002), In situ fixation of metals in soils using bauxite residue: biological effects, Environmental Pollution, 118, 445452.

Moon D.H., Cheong K.H., Chang Y.Y., Baek K., Jo R. and Park Y.H. (2016), Assessment of soil washing for simultaneous removal of heavy metals and low-level petroleum hydrocarbons using various washing solutions, Environmental Earth Sciences, 75, 884-892.

Mulligan C.N., Yong R.N. and Gibbs B.F. (2001a), Remediation technologies for metal-contaminated soils and groundwater: an evaluation, Engineering Geology, 60, 193-207.

Mulligan C.N., Yong R.N. and Gibbs B.F. (2001b), An evaluation of technologies for the heavy metal remediation of dredged sediments, Journal of Hazardous Materials, 85, 145-163.

Nzihou A. and Sharrock P. (2010), Role of Phosphate in the Remediation and Reuse of Heavy Metal Polluted Wastes and Sites, Waste Biomass Valor, 1, 163-174.

Paulose B., Datta S.P., Rattan R.K. and Chhonkar P.K. (2007), Effect of amendments on the extractability retention and plant uptake of metals on sewage-irrigated soil, Environmental Pollution, 146, 19-24. 
Pavel B.P., Puschenreiter M., Wenzel W. and Barbu C-H (2014), Aided phytostabilization using Miscanthus sinensis $\times$ giganteus on heavy metal-contaminated soils, Science of the Total Environment, 479-480, 125-131.

Polish Standard PN-77/G-04528-00PN-77/G-04528/00. Solid fuels. Determination of chemical composition of ash. Preparation of ash sample and solution for testing.

Ram L.C. and Masto R.E. (2014), Fly ash for soil amelioration: A review on the influence of ash blending with inorganic and organic amendments, Earth-Science Reviews, 128, 52-74.

Regulation of the Minister of Environment of 9 September 2002 on standards of quality of the soil and earth quality standard (Dz.U. 2002, Nr 165, poz. 1359) - in polish.

Report on the Environment (ROE), Environmental Protection Agency (2015), USA.

Report on the Environment (CSOP), Central Statistical Office (2015), Warszawa, Poland - in polish.

Saletnik B., Bajcar M., Zaguła G., Czernicka M. and Puchalski C. (2016), Influence of biochar and biomass ash applied as soil amendment on germination rate of Virginia mallow seeds (Sidahermaphrodita R.), ECONTECHMOD - an International Quarterly Journal, 5, 71-76.

Shi W.Y., Shao H., Li H., Shao M. and Du S. (2009), Progress in the remediation of hazardous heavy metal-polluted soils by natural zeolite, Journal of Hazardous Materials, 170, 1-6.

Sonmez O. and Pierzynski G.M. (2005), Phosphorus and manganese oxides effects on soil lead bioaccessbility: PBET and TCLP, Water, Air, and Soil Pollution, 166, 3-16.

Suér P., Gitye K. and Allard B. (2003), Speciation and transport of heavy metals and macroelements during electroremediation, Environmental Science Technology, 37, 177-181.

Sun Y., Zhao D., Xu Y., Wang L., Liang X. and Shem Y. (2016), Effects of sepiolite on stabilization remediation of heavy metal-contaminated soil and its ecological evaluation, Frontiers of Environmental Science \& Engineering, 10, 85-92.

Teng Y., Feng D., Wu J., Rui Z., Song L. and Wang J. (2015), Distribution, bioavailability, and potential ecological risk of $\mathrm{Cu}, \mathrm{Pb}$, and $\mathrm{Zn}$ in soil in a potential groundwater source area, Environmental Monitoring and Assessment, 187, 293.

Verdugo C., Sánchez P., Santibáňez C., Urrestarazu P., Bustamante E., Siva Y., Gourdon D. and Ginocchio R. (2011), Efficacy of lime, biosolids, and mycorrhiza for the phytostabilization of sulfide copper tailings in Chile: a greenhouse experiments, International Journal of Phytoremediation, 13, 107-125.

Voglar G.E. and Leŝtan D. (2010), Solidification/stabilization of metals contaminated industrial soil from former $\mathrm{Zn}$ smelter in Celje, Slovenia, using cement as hydraulic binder, Journal of Hazardous Materials, 178, 926-933.

Warren G.P., Allowey B.J., Lepp N.W. and Penny C. (2003), Field trials to assess the uptake of arsenic by vegetables from contaminated soil and soil remediation with iron oxides, The Science of the Total Environment, 311, 19-33.

Xia W., Gao H., Wang X., Zhou C., Liu Y., Fana T. and Wang X. (2009), Application of EDTA decontamination on soils affected by mining activities and impact of treatment on the geochemical partition of metal contaminants, Journal of Hazardous Materials, 164, 936-940.
Zhang W., Tong L., Yuan Y., Liu Z., Huang H., Tan F. and Qiu R. (2010), Influence of soil washing with chelator on subsequent chemical immobilization of heavy metals in a contamined soil, Journal of Hazardous Materials, 178, 578587. 